\title{
Comparison of the effects of low-level laser and pulsed and continuous ultrasound on pain and physical disability in chronic non- specific low back pain: a randomized controlled clinical trial
}

\author{
Ana Paula Fernandes De Angelis Rubira', Marcelo Custódio Rubira², Lucas De Angelis Rubira ${ }^{3}$, \\ Josielli Comachio $^{1 *}$ (D), Maurício Oliveira Magalhães ${ }^{1}$ and Amélia Pasqual Marques ${ }^{1}$
}

\begin{abstract}
Objective: To compare the short-term effects of pulsed laser and pulsed and continuous ultrasound on pain and functional disability in women with chronic non-specific low back pain.

Methods: The sample was composed of 100 volunteers randomly allocated into four groups: The Pulsed Laser Group $(n=26)$ was treated with $3 \mathrm{~J} / \mathrm{cm}^{2}$; the Pulsed Ultrasound Group $(n=24 ; 3 \mathrm{MHz})$ was treated with $1 \mathrm{~W} / \mathrm{cm}^{2}$; the Continuous Ultrasound Group $(n=26 ; 1 \mathrm{MHz})$ was treated with $1 \mathrm{~W} / \mathrm{cm}^{2}$; and a Control Group $(n=24)$, where the patients were still waiting for treatment. Before and after 10 sessions of treatment, the intensity of pain was assessed using the visual analogue scale (VAS), the quality of pain was evaluated using the McGill pain questionnaire and functional disability was investigated using the Roland-Morris questionnaire.
\end{abstract}

Results: The three treated groups exhibited a decrease in pain $(p<0.001)$; the Pulsed Laser Group showed the greater relative gain (91.2\%), Meanwhile, the Control Group exhibited a worsening of $-5.8 \%$. The three treated groups demonstrated improvement in the quality of pain (McGill) in the total, sensory and affective dimensions $(p<0.005 ; p<0.002 ; p<0.013$, respectively). All treated groups showed a decrease in functional disability $(p<0.001)$, but the Pulsed Ultrasound Group showed the highest relative gain (83.3\%).

Conclusions: The three modalities have significant effects to decreasing low back pain and improving functional disability in women with non-specific chronic low back pain, but the pulsed low-level laser had the best results on pain while the pulsed ultrasound had the best results on improve the functional disability.

Trial registration: ClinicalTrials.gov: NCT02150096.

Keywords: Low back pain, Laser therapy and ultrasound therapy

\footnotetext{
* Correspondence: josiellicomachio@usp.br

${ }^{1}$ Physical Therapy, Speech and Occupational Therapy Department, School of Medicine, University of Sao Paulo, Cipotânea, n 51, Cidade Universitária, Sao Paulo, Brazil

Full list of author information is available at the end of the article
}

(c) The Author(s). 2019 Open Access This article is distributed under the terms of the Creative Commons Attribution 4.0 International License (http://creativecommons.org/licenses/by/4.0/), which permits unrestricted use, distribution, and reproduction in any medium, provided you give appropriate credit to the original author(s) and the source, provide a link to the Creative Commons license, and indicate if changes were made. The Creative Commons Public Domain Dedication waiver (http://creativecommons.org/publicdomain/zero/1.0/) applies to the data made available in this article, unless otherwise stated. 


\section{Introduction}

Low back pain (LBP) is one of most widespread and expensive public health problems in developed countries. Moreover, it is an important cause of work absenteeism worldwide, as well as affecting the quality of life of sufferers and their individual functional performances [1-3].

Low back pain can be defined as a regional pain which is anatomically distributed between the last rib and the gluteal fold [4], extending to one or both lower limbs [5], often accompanied by exacerbation of pain and limitation of movement [4]. It is considered a pathology in the 10th revision of the International Code of Diseases by the World Health Organisation [6]. Low back pain is a major reason for visits to health professionals [7, 8]. In terms of the causes of low back pain, $5-15 \%$ are related to severe diseases of the spine; however, about $85 \%$ of cases have a diagnosis of non-specific low back pain, which does not have a well-defined etiology [1].

Low back pain can cause functional disability, a wide range of therapeutic interventions are available to treat it [9]; amongst these, low-level laser therapy (LLLT) and ultrasound are two options. According to Wright and Schiffman, [10] low level laser therapy can generate a response without producing heat in the tissues, and its analgesic and anti-inflammatory effects are due to its ability to increase capillary permeability. The laser analgesic effect is due to increased secretion of endogenous opioids such as $\beta$-endorphins, by which the pain is centrally inhibited [11]. However, the mechanism of analgesia has not been well established but has been attributed to the antiinflammatory and bio-stimulating effects of laser [12, 13].

The use of ultrasound in musculoskeletal disorders is an intervention that is frequently used by physical therapists [14]. Its effects are classified as thermal or non-thermal, although the two effects do not always occur in isolation [15-17]. Therapeutic ultrasound promotes beneficial effects such as improved blood flow, decreased joint stiffness and muscle spasms, [18] increased range of motion and reduction of oedema, $[19,20]$. With respect to the theory on the effectiveness and working mechanisms of ultrasound, a large amount of literature is available. However, further study is needed because previous results as to their effectiveness have been contradictory in patients with chronic low back pain [15]. Evidence of its effectiveness has come mainly from clinical parameters in pain studies [21, 22].

In the literature, we do not identified study what compared the isolated effects between these treatment modalities in order to clarify which treatment must has better effect in the reduction of pain, as soon as there are several other reasons for providing interventions to patients with low back pain. The purpose of this study was to compare the short-term effects of pulsed low-level laser therapy and continuous and pulsed ultrasound on pain and functional disability in women with chronic non-specific low back pain.

\section{Methods}

A single blind randomized controlled trial registered with the Clinicaltrial.gov (NCT02150096). All patients signed the free and informed consent before the start of the treatment.

The evaluator of the results was blinded for the allocation of patients. Only women were chosen because the sex differences in pain perception, [23-26] and included with a diagnosis of chronic non-specific low back pain in only regions 36 and 37 of body pain map [27] (without medication use for pain or compensation in the lumbar spine and to standardize the recruitment), who had been symptomatic for more than 4 months - thereby allowing their pain to be characterised as chronic, [28] with pain between 4 and 7 on the visual analogue scale (VAS) at the time of assessment to keep homogeneity of pain (for less standard deviation) and with eutrophics (normal body mass index). We included women aged between 18 to 40 years old $[29,30]$ and excluded women with dental emergency; metabolic diseases (e.g. diabetes or hyperthyroidism); osteoporosis; abrasions on the skin at the sites of application of therapies [31]; neurological disorders (e.g. dyskinesia); vascular disease (e.g. hypertension) [32]; rheumatic diseases; neoplasms [33]; and drug abuse. We also excluded pregnant [32, 34] or lactating women; victims of recent vehicle accidents or with sequelae from such accidents; those using analgesics, anti-inflammatories or psychotropic medication [35]; and patients with herniated discs, spine fractures, spondylolisthesis [36], kidney calculi or any other diagnosis which proved to be the cause of low back pain. The exclusion criteria were chosen to minimize the confusion variables.

\section{Sample}

The sample size was defined in order to detect a 2-point difference between groups on the pain intensity outcome measurement on VAS [37, 38], assuming a standard deviation of 2 points. Power was defined as $80 \%$ for an alpha of $5 \%$ and attrition (dropouts) of 15\%. Accordingly, 22 participants per group were required.

The participants were referred for physiotherapeutic treatment at a physical therapy clinic or screened in the community. Before the evaluation, they were randomly divided into four groups using SigmaStat, as follows: A Pulsed Laser Group (PLG; $n=29$ ); a Pulsed Ultrasound Group (PUSG; $n=28$ ); a Continuous Ultrasound Group (CUSG; $n=30$ ); and a Control Group (CG; $n=24$ ) representing patients awaiting treatment. The participants were selected after the application of the pain map $[39,40]$.

\section{Randomization}

The randomization of the sample was carried out by computer. The results of randomization were sealed in envelopes to ensure the confidentiality of the order of 
allocation of groups, and each envelope was only opened after the initial assessment of each participant.

\section{Intervention}

To ensure allocation secret, continuous ultrasound and pulsed ultrasound application were standardised in the lumbar region, on the spinalis, erector spinae muscles and on the region of the multifidus which is below the two muscles mentioned above on the scoop between the spinous and transverse processes right and left of the lumbar vertebrae (1st, 3rd and 5th) due these regions were more trigger points. The volunteers remained lying in the prone position on a divan with an opening to rest the face and head, with a pillow under the abdomen to avoid the interference of unwanted muscle contractions of the muscles of the lumbar spine while the procedure was being carried out (Fig. 1).

\section{Pulsed low-power laser}

The participants received application of laser with an arsenic and gallium (ASGA) infrared wavelength of 904 $\mathrm{nm}$, a contact area of $0.13090 \mathrm{~cm}^{2}$, average power of $0.04 \mathrm{~W}$, peak power of $70 \mathrm{~W} \pm 20 \%$, duration of pulse of $60 \mathrm{~ns}$, pulsed emission of $9500 \mathrm{~Hz}$, laser class 3B, appliance model Laser Pulse (IBRAMED ${ }^{\circ}$ ) and a wavelength that followed the international standard IEC 825-1 (1993-11) and NBR IEC 60601-2-22 (1997-10). For the application of the pulsed low-power laser, the punctual technical was chosen, with dosimetry of $3 \mathrm{~J}$, and an exposure time of $75 \mathrm{~s}$ in each treated area and final density of $18 \mathrm{~J}$ ( $7 \mathrm{~min}$ and $30 \mathrm{~s})$, totally were applied 6 points.

\section{Pulsed ultrasound}

The PUSG received pulsed ultrasound application with a transducer operating at a frequency of $3 \mathrm{MHz}$, in the pulsed emission modality.

\section{Continuous ultrasound}

The CUSG received application of continuous ultrasound with a transducer operating at a frequency of $1 \mathrm{MHz}$, in the continuous emission modality. Both the 3 and $1 \mathrm{MHz}$ modalities had WAS ERA of $3.5 \mathrm{~cm}^{2}$ and a mean power output of $7 \mathrm{~W}$. Both ultrasound groups received dosimetry of intensity of $1 \mathrm{~W} / \mathrm{cm}^{2}$ for $2 \mathrm{~min}$ continuously at each point standardised in the lumbar spine, totalling 12 min. The treatment time was calculated using Grey's formula [41].

\section{Evaluation}

A blinded examiner performed the evaluations of patients immediately when they were selected and at the end of 10 sessions of treatment (4weeks), except for pain (as recorded in the VAS), which was completed daily before the beginning and $5 \mathrm{~min}$ after the end of treatment.

The participants of control group were awaiting treatment, they were just evaluated and after the period of 4 weeks were reassessed. The pain was registered in the VAS only two times. The patients in the three experimental groups were treated three times per week on intercalated days totalling 10 sessions. They and the control group were instructed to continue without analgesics, anti-inflammatories or muscle relaxants, along with any other type of medication or treatment for pain or psychotropic medication during 10 sessions until the

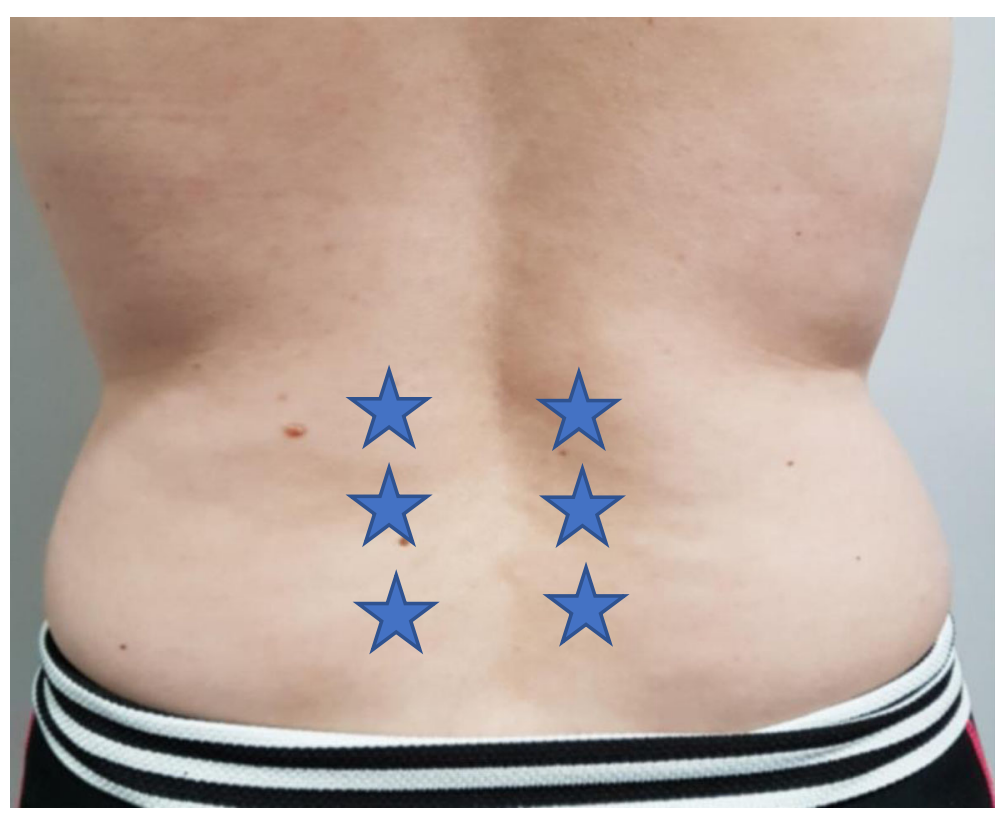

Fig. 1 Location of points for pulsed laser, pulsed ultrasound and continuous ultrasound treatment in the lumbar spine 
reassessment. The frequencies were chosen to verify if the profound or superficial wave is more effective, and if wave or light is more effective.

\section{Primary parameter}

The primary parameter was as follows:

$>$ Pain: The pain was measured daily before each treatment and $5 \mathrm{~min}$ after the end of each treatment, with the patient indicating her current level of pain by marking a point on a $10 \mathrm{~cm}$ VAS. On this scale, 0 represents the absence of pain and 10 represents unbearable pain.

\section{Secondary parameters}

The secondary parameters were as follows:

$>$ Quality of pain: For the quality of pain assessment, the McGill questionnaire [42, 43] adapted to the Portuguese used before and after the treatment [37]. This considers pain according to three dimensions, namely the sensorydiscriminative, affective-motivational and cognitiveevaluative dimensions. It is used to qualitatively and quantitatively assess the pain experience and is organised into four categories - sensory, affective, evaluative and mixed - with 20 subcategories and 67 words descriptors describing the quality of pain. The score (a total of 6 points) is calculated according to the number of words chosen; there are 34 words in the sensory category, 14 words in the affective category, 5 words in the evaluative category and 11 words in the mixed category. As to the assessment index of pain, this represents the sum of the values added to each word chosen in each of the dimensions. Thus, it is 1 to 10 as sensory; 11 to 15 as affective; 16 as evaluative; and 17 to 20 as mixed. $>$ Functional disability evaluation: Functional disability was assessed using the Roland-Morris questionnaire, which comprises 24 questions related to pain and function. The questions are straightforward and simple, giving a score of 1 for each statement the participant agrees with and 0 for each statement the participant does not agree with. The values are added together and obtain a minimum score of 0 and a maximum score of 24. Higher values indicate a worse low back pain condition [44]. The cut-off point for this questionnaire is 14; with a score above 14 points, the respondent is considered to have functional disability.

\section{Statistical analysis}

For the presentation of the frequency data, some demographic variables and percentages (\%) were used. The normality of all data was assessed using the Kolmogorov-Smirnov test. In all statistical tests, the significance level was set at $5 \%$. Intragroup analyses were performed using Wilcoxon's non-parametric test. Intergroup analyses were performed using Kruskal-Wallis analysis of variance. The groups were compared pre and post treatment. Statistically significant differences were identified using the post hoc Dunn's test (non-parametric). The statistical analysis in this study was performed using the Windows Excel and Sigma Stat 3.5 software.

For the three treated groups, the relative gain was calculated as a way of evaluating the results to determine clinically important differences, because many times there were no statistically significant differences. This is a parameter corresponding to the gain that the patients have experienced after the end of treatment, representing the degree of improvement. For low back pain, the clinical relative gain needed to be above $15 \%$ in comparison to the gain of the control group [8]. The relative gain was calculated with the initial VAS of the first treatment day and the last VAS of the last treatment day and using the equation shown in Fig. 2.

\section{Results}

One hundred eighty-seven patients with non-specific chronic low back pain were screened and, 111 patients who fulfilled the eligibility criteria were selected. The Fig. 3 showed flow diagram of the study. The demographic data are presented in Table 1, the demographic data demonstrates no significant differences.

Table 2 shows the comparison between the groups before treatment. There was no statistically significant difference between the groups in parameters of pain intensity or all dimensions of in quality of pain. In the post-treatment assessment, there were no statistically significant differences $(p<0.05)$ in pain (VAS) or quality of pain (McGill) in the total and sensory dimensions. All treated groups were statistically different when compared to the control group. The LG was statistically different from the PUSG and CUSG, demonstrating the greatest decrease in pain (VAS). The CUSG was statistically different from PUSG, exhibiting a greater reduction in pain. About the quality of pain (McGill and total sensory), the three treated groups were statistically different only from the control group, but not amongst them.

\section{Discussion}

The purpose of the present study was to compare the short-term effects of pulsed laser and pulsed and continuous ultrasound on pain and functional disability in women with chronic non-specific low back pain. In the

$$
1 \text { min }=\frac{\text { exposition } \text { area }^{2}}{\text { area of the transducer head }}=\text { time }
$$

Fig. 2 Grey's formula $1 \mathrm{~min}=\frac{\text { exposition area }{ }^{2}}{\text { area of the transducer head }}=$ time 


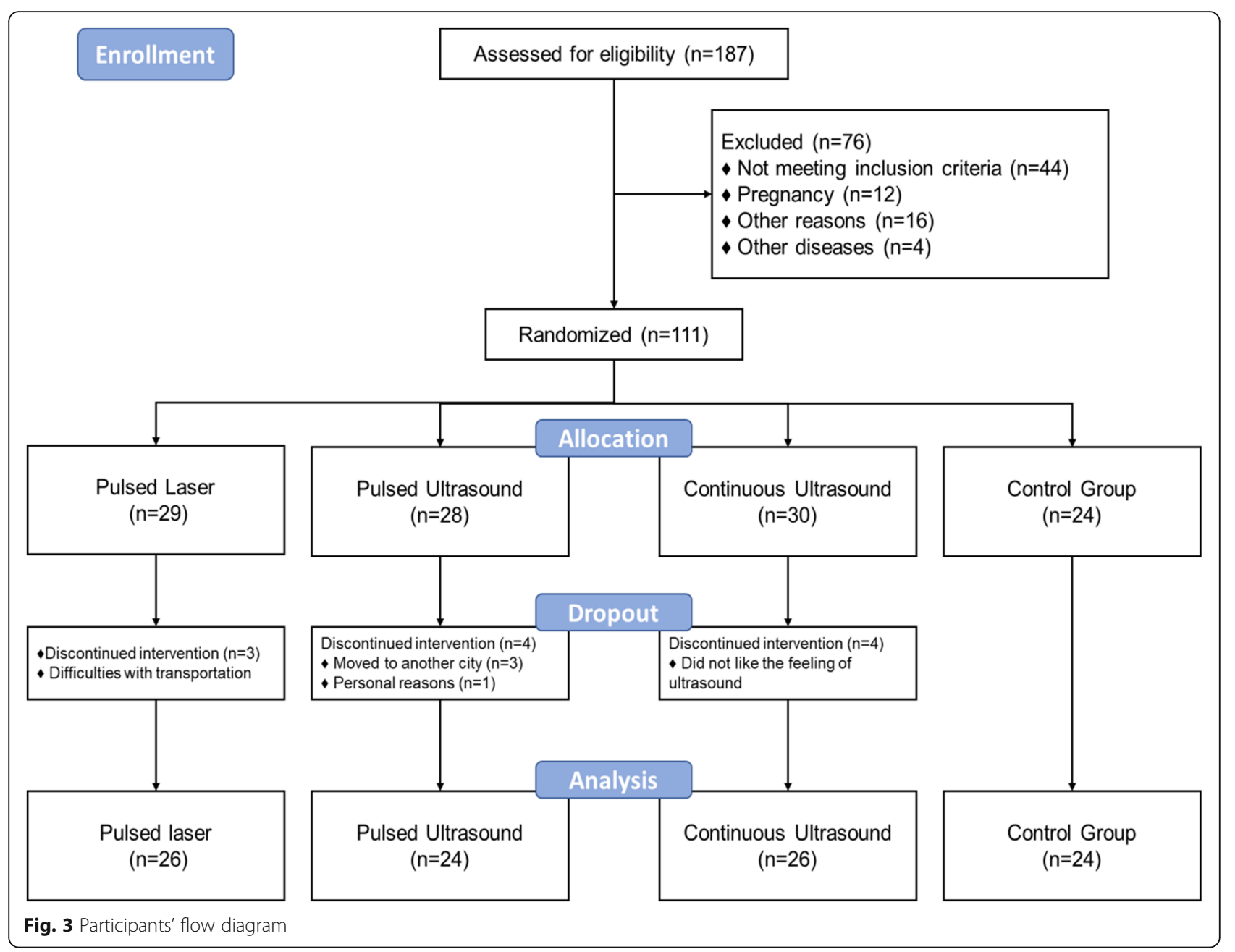

study, all treated groups exhibited improvement in pain, but the LG demonstrated the best results.

In physical therapy practice, the laser and ultrasound modalities are used extensively in musculoskeletal injuries because of their ability to relieve pain and inflammation effects [10], and the laser has low-cost for the patients [45]. In the present study, all treated groups exhibited improvement in pain, but the LG obtained the best results.

Although laser and ultrasound have similar effects, the absorption occurs differently in different types of tissue, and therefore, signifying a great difference between them [10]. The radiation emitted by laser has a low absorption coefficient and results in maximum penetration in tissues [46]; however, to penetrate the tissues and be absorbed, the radiation releases histamine, serotonin, prostaglandin and bradykinin, and thus may inhibit or stimulate cell and enzyme activity [47].

Another effect attributed to the laser that differs from that of ultrasound is the elimination of glucocorticoids [48]. Laser also alters the morphology of mitochondria in the perinuclear region at 24 to $48 \mathrm{~h}$ after irradiation, in addition to providing the training of giants mitochondria [49]. Laser irradiation results in calcium homeostasis, manufacture of oxygen and control of apoptosis in several pathophysiological conditions [50].

In the present study, $1 \mathrm{MHz}$ and $3 \mathrm{MHz}$ of continuous and pulsed ultrasound, respectively, were selected; the continuous ultrasound exhibited better results than the pulsed laser in relation to pain. The $1 \mathrm{MHz}$ continuous ultrasound reaches a greater depth in tissues, and increases vasodilation and local blood flow by modulating pain, reducing muscle spasm sites and increasing the extensibility of collagen $[51,52]$. However, in terms of the improvement in functional disability, the PUSG showed superior results to the LG, CUSG and CG. The nonthermal effects of pulsed ultrasound may explain the improvement in functional disability. Stable cavitation consists of gas bubbles which expand and contract due to changes in pressure repeated over many acoustic cycles, representing a kind of micro-massage at the site and reducing muscle spasms [53]. Also, the micro-flow produces tension in highly viscous substances, and can alter 
Table 1 Demographic characteristics of the groups at baseline

\begin{tabular}{|c|c|c|c|c|}
\hline Variables & $\begin{array}{l}\text { Pulsed laser }(n=29) \\
(\text { Mean/SD) }\end{array}$ & $\begin{array}{l}\text { Pulsed ultrasound }(n=28) \\
\text { (Mean/SD) }\end{array}$ & $\begin{array}{l}\text { Continuous ultrasound }(n=30) \\
\text { (Mean/SD) }\end{array}$ & $\begin{array}{l}\text { Control }(n=24) \\
\text { (Mean/SD) }\end{array}$ \\
\hline Age (years) & $22.17(4.68)$ & $22.92(4.60)$ & $22.83(5.22)$ & $22.37(4.32)$ \\
\hline BMI $\left(\mathrm{kg} / \mathrm{cm}^{2}\right)$ & $21.98(2.13)$ & $21.72(2.27)$ & $21.88(1.64)$ & $22.03(1.93)$ \\
\hline \multicolumn{5}{|l|}{ Marital status (\%) } \\
\hline Married & $4(13.8)$ & $5(17.8)$ & $5(16.7)$ & $2(8.3)$ \\
\hline Unmarried & $24(82.7)$ & $22(78.6)$ & $24(80.0)$ & $22(91.7)$ \\
\hline Divorced & $1(3.5)$ & $1(3.6)$ & $1(3.3)$ & - \\
\hline \multicolumn{5}{|l|}{ Education (\%) } \\
\hline University & $1(3.5)$ & $1(3.6)$ & $1(3.3)$ & - \\
\hline High school & $25(86.0)$ & $26(92.8)$ & $26(86.7)$ & $20(83.4)$ \\
\hline Middle school & $3(10.5)$ & $1(3.6)$ & $3(10.0)$ & $4(16.6)$ \\
\hline \multicolumn{5}{|l|}{ Occupation (\%) } \\
\hline Student & $25(86.0)$ & $25(89.2)$ & $25(83.5)$ & $20(83.4)$ \\
\hline Other & $4(14.0)$ & $3(10.8)$ & $5(16.5)$ & $4(16.6)$ \\
\hline \multicolumn{5}{|l|}{ Physical activity (\%) } \\
\hline Yes & $10(35.7)$ & $9(32.1)$ & $9(30.0)$ & $8(33.4)$ \\
\hline Daily pain (\%) & $31(9.0)$ & $32.2(9.0)$ & $43.3(13.0)$ & $20.9(5.0)$ \\
\hline Pain/daily duration (h) & $4(1-5)$ & $5(3.5-5)$ & $3(2-5)$ & $5(2-5)$ \\
\hline Up to 5 h (\%) & $16(55.2)$ & $13(44.4)$ & $17(56.7)$ & $10(41.7)$ \\
\hline All day (\%) & $13(44.8)$ & $15(55.6)$ & $13(43.3)$ & $14(58.3)$ \\
\hline Pain/duration (months) & $5(4.7-5)$ & $5(5-5)$ & $5(5-5)$ & $5(5-5)$ \\
\hline 4 to $12(\%)$ & $7(24.1)$ & $5(17.9)$ & $4(13.3)$ & $5(20.8)$ \\
\hline Above 12 (\%) & $22(75.9)$ & $23(82.1)$ & $26(86.7)$ & $19(79.2)$ \\
\hline Pain on awaking $(\mathrm{cm})$ & $2(2-3)$ & $3(1-3)$ & $2(2-3)$ & $3(1.5-3)$ \\
\hline Yes (\%) & $5(17.2)$ & $10(35.7)$ & $7(23.3)$ & $6(25.0)$ \\
\hline Awaking in the night due to pain & $2(2-2)$ & $2(2-3)$ & $2(2-2)$ & $2(2-3)$ \\
\hline Yes (\%) & $3(10.3)$ & $4(14.3)$ & $3(10.0)$ & $4(16.7)$ \\
\hline Painful positions & $2(1-3)$ & $3(2-3)$ & $2(2-3)$ & $2(1-3)$ \\
\hline Sitting (\%) & $9(31.0)$ & $12(42.8)$ & $7(23.3)$ & $7(29.2)$ \\
\hline Orthostatic position (\%) & $10(34.5)$ & $6(21.5)$ & $9(30.0)$ & $9(37.5)$ \\
\hline Several positions (\%) & $10(34.5)$ & $10(35.7)$ & $14(46.7)$ & $8(33.3)$ \\
\hline Sudden attacks of pain (\%) & $15(51.8)$ & $14(50.0)$ & $11(36.7)$ & $13(54.2)$ \\
\hline Average pain/ Lasting four weeks (cm) & $7(4-8)$ & $7(6.5-8)$ & $6(5-7)$ & $6(4.5-8)$ \\
\hline
\end{tabular}

$\mathrm{Kg} / \mathrm{cm}^{2}$ Kilograms per square centimetre, SD standard deviation, Sup superior, $B M I$ body mass index, $\%$ percentage. $P=0.05$

the permeability of the cell membrane to sodium and calcium ions, which is important in the tissue healing process $[15,18,51,54]$.

For more evidence of the effects of pulsed low-level laser therapy, pulsed ultrasound and continuous ultrasound, other randomized controlled trials should be carried out with appropriate samples. Moreover, studies should be conducted on the effects of gender; dosimetry, using suitable calculations; and tests of calibrated equipment for which there is a homogeneous of method. This will allow comparison of the results. It is also necessary to monitor the therapy in the medium and long term, as well as to use placebo groups as a way of obtaining more consistent data, resulting in studies with greater reliability.

The present study had some limitations. No follow-up was carried out and the results are only in the short term. Another limitation is the lack of a placebo group which is difficult to be authorized by the Committee for Ethics in Research. Complementary examinations such as image were also limiting factor in the diagnosis of low back pain not specific, although the age range of the sample already delete many cases of specific low back pain. 
Table 2 Comparison of the treated groups pre- and post-treatment and the control group for the evaluation and re-evaluation

\begin{tabular}{|c|c|c|c|c|c|}
\hline Variables & $\begin{array}{l}\text { Pulsed laser }(n=26) \\
\text { Median }(25-75 \%)\end{array}$ & $\begin{array}{l}\text { Pulsed ultrasound }(n=24) \\
\text { Median }(25-75 \%)\end{array}$ & $\begin{array}{l}\text { Continuous ultrasound }(n=26) \\
\text { Median }(25-75 \%)\end{array}$ & $\begin{array}{l}\text { Control }(n=24) \\
\text { Median }(25-75 \%)\end{array}$ & $p$ \\
\hline \multicolumn{6}{|l|}{ 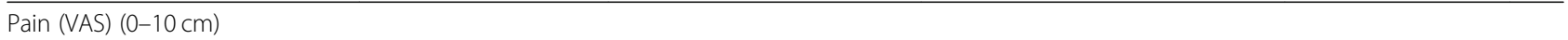 } \\
\hline Pre & $5.7(4.8-7)$ & $6(4.2-6.9)$ & $5.9(4.9-6,7)$ & $6(5-7)$ & 0.791 \\
\hline Post & $0.5(0.1-8)^{*+\#}$ & $1.4(0.8-3) * * €$ & $1.1(0.4-7)^{+¥ £}$ & $6.3(5-7.2){ }^{\# \in £}$ & 0.001 \\
\hline Difference between groups & $4.8(1.3) *$ & $3.7(2.0)^{+}$ & $3.7(2.0)^{\#}$ & $-0.2(1.7)^{*+\#}$ & 0.001 \\
\hline \multicolumn{6}{|l|}{ Pain (McGill - total) (0-67) } \\
\hline Pre & $23.5(18-33)$ & $28.5(24-34.5)$ & $24(20-29)$ & $24(20-30.5)$ & 0.213 \\
\hline Post & $9.5(3-23) *$ & $13.5(2.5-24.5)^{+}$ & $12(5-20){ }^{\#}$ & $34(16.5-42.5)^{*+\#}$ & 0.005 \\
\hline Difference between groups & $10.76(14.32) *$ & $12.41(14.52)^{+}$ & $11.03(16.26)^{\#}$ & $-26.54(16.22) *+\#$ & 0.001 \\
\hline \multicolumn{6}{|l|}{ Sensory (0-34) } \\
\hline Pre & $13.5(10-19)$ & $16.5(10-20)$ & $15(12-22)$ & $15.5(13-19)$ & 0.84 \\
\hline Post & $6.5(0-12) *$ & $7(2-15)^{+}$ & $9(3-13){ }^{\#}$ & $19(10.5-23.5)^{*+\#}$ & 0.002 \\
\hline Difference between groups & $6.1(8.0)$ & $6.0(8.1)$ & $7.1(11.3) \#$ & $-0.5(8.4)^{\#}$ & 0.026 \\
\hline \multicolumn{6}{|l|}{ Affective (0-17) } \\
\hline Pre & $6(4-7)$ & $5(4-6.5)$ & $5(3-8)$ & $5(3-6)$ & 0.794 \\
\hline Post & $2(0-6) *$ & $2.5(0-5.5)^{+}$ & $2(1-5)^{\#}$ & $7(2-9.5)^{*+\#}$ & 0.013 \\
\hline Difference between groups & $2.3(3.8) *$ & $2.2(3.4)^{+}$ & $2.6(4.2){ }^{\#}$ & $-1.3(4.2)^{*+\#}$ & 0.003 \\
\hline \multicolumn{6}{|l|}{ Functional disability (0-24) } \\
\hline Pre & $4(4-7)$ & $6(3-8.5)$ & $4(3-7)$ & $4(3-8)$ & 0.83 \\
\hline Post & $1.5(1-4) *$ & $1(0-4.5)^{+}$ & $2(1-4)^{\#}$ & $5.5(3-8) *+\#$ & 0.001 \\
\hline Difference between groups & $2.9(2.3) *$ & $2.9(2.8)^{+}$ & $2.4(3.0)^{\#}$ & $-0.04(2.3)^{*+\#}$ & 0.001 \\
\hline
\end{tabular}

* No statistically significant difference in Kruskal-Wallis non-parametric ANOVA for $p<0.05$. Statistically different group from the others in the post hoc Dunn's test $\left(^{*} p<0.05 ;+p<0.05 ; \# p<0.05 ; ¥ p<0.05 ; € p<0.05 ; € p<0.05\right)$

\section{Conclusion}

The pulsed low-power laser and pulsed and continuous ultrasound have significant short-term effects when it comes to reducing pain and improving functional disability in woman patients with non-specific chronic low back pain. However, in terms of the improvement in functional disability and when compared the groups, the PUSG showed superior results to the LG, CUSG and CG.

\section{Clinical messages}

- Pulsed low-power laser and pulsed and continuous ultrasound have significant short-term effects when it comes to reducing pain and improving functional disability in patients with non-specific chronic low back pain.

- In a comparison of pulsed laser, and pulsed and continuous ultrasound, the pulsed laser has more significant effects in decreasing pain, while pulsed ultrasound was superior in improving functional disability.

\section{Abbreviations}

ASGA: laser with an arsenic and gallium; CUSG: Continuous Ultrasound Group; LBP: Nonspecific low back pain; NRS: Numerical Rating Scale;"
PLG: Pulsed Laser Group; PUSG: Pulsed Ultrasound Group; SD: Standard deviation; SF36: Short Form Health Survey Questionnaire; VAS: Visual analogue scale

\section{Acknowledgements}

We appreciated all patients who agreed to participate in the study.

\section{Authors' contributions}

APR; had the idea of study, wrote, analyzed and interpreted the patient data regarding. MR; who helped analyzed and contributed with the recruited of patients. LR; who did statistical analyses and reviewed the article. JC; who reviewed the article and helped with the write. MM; who reviewed the article and helped with the write. APM; who supervision of the study. All authors read and approved the final manuscript.

\section{Funding}

This study did not receive financial resources.

\section{Availability of data and materials \\ Not applicable.}

\section{Ethics approval and consent to participate}

Ethics approval and consent to participate This study was approved by the ethics committee of the School of Medicine of the University of Sao Paulo (Protocol 390/10) and all participants gave their informed consent before participation according to 196/96 regulation.

Consent for publication

All patients and healthy controls signed the consent for publication.

Competing interests

The authors declare that they have no competing interests. 


\section{Author details}

'Physical Therapy, Speech and Occupational Therapy Department, School of Medicine, University of Sao Paulo, Cipotânea, n 51, Cidade Universitária, Sao Paulo, Brazil. ${ }^{2}$ Faculty of Biomedical Sciences of Cacoal (FACIMED), Cacoal, Rondonia, Brazil. 'Department of Medicine, São Lucas College, Porto Velho, Rondônia, Brazil.

Received: 18 February 2019 Accepted: 18 November 2019

Published online: 17 December 2019

\section{References}

1. Koes B, Van Tulder M, Thomas S. Diagnosis and treatment of low back pain. BMJ. 2006;332(7555):1430.

2. Balagué $F$, Mannion AF, Pellisé $F$, Cedraschi C. Non-specific low back pain. Lancet. 2012:379(9814):482-91.

3. Martin BI, Deyo RA, Mirza SK, Turner JA, Comstock BA, Hollingworth W, et al. Expenditures and health status among adults with back and neck problems. JAMA. 2008;299(6):656-64.

4. Kovacs FM, Muriel A, Abriaira V, Medina JM, Castillo Sanchez MD, Olabe J. The influence of fear avoidance beliefs on disability and quality of life is sparse in Spanish low back pain patients. Spine (Phila Pa 1976). 2005;30(22):E676-82.

5. Hoy D, March L, Brooks P, Woolf A, Blyth F, Vos T, et al. Measuring the global burden of low back pain. Best Pract Res Clin Rheumatol. 2010;24(2): 155-65.

6. Senna ER, De Barros AL, Silva EO, Costa IF, Pereira LV, Ciconelli RM, et al. Prevalence of rheumatic diseases in Brazil: a study using the COPCORD approach. J Rheumatol. 2004;31(3):594-7.

7. Andersson GB. Epidemiological features of chronic low-back pain. Lancet. 1999;354(9178):581-5.

8. Philadelphia P. Philadelphia panel evidence-based clinical practice guidelines on selected rehabilitation interventions for low back pain. Phys Ther. 2001;81(10):1641-74.

9. Smeets RJ, Severens JL, Beelen S, Vlaeyen JW, Knottnerus JA. More is not always better: cost-effectiveness analysis of combined, single behavioral and single physical rehabilitation programs for chronic low back pain. Eur J Pain. 2009;13(1):71-81.

10. Watson T. Ultrasound in contemporary physiotherapy practice. Ultrasonics. 2008;48(4):321-9.

11. Hagiwara S, Iwasaka H, Hasegawa A, Noguchi T. Pre-irradiation of blood by gallium aluminum arsenide $(830 \mathrm{~nm}$ ) low-level laser enhances peripheral endogenous opioid analgesia in rats. Anesth Analg. 2008;107(3):1058-63.

12. Bjordal JM, Klovining A, Ljunggren AE, Slordal L. Photoradiation in acute pain: a systematic review of possible mechanisms of action and clinical effects in randomized placebo-controlled trials. Photomed Laser Surg. 2006; 24(2):158-68.

13. Gocevska M, Nikolikj-Dimitrova E, Gjerakaroska-Savevska C. Effects of high intensity laser in treatment of patients with chronic Low Back pain. Open Access Maced J Med Sci. 2019;7(6):949-54.

14. Medlicott MS, Harris SR. A systematic review of the effectiveness of exercise, manual therapy, electrotherapy, relaxation training, and biofeedback in the management of temporomandibular disorder. Phys Ther. 2006;86(7):955-73.

15. Baker KG, Robertson VJ, Duck FA. A review of therapeutic ultrasound: biophysical effects. Phys Ther. 2001;81(7):1351-8.

16. Cameron Ml. Agentes físicos na reabilitação: da pesquisa à prática. Editora Elsevier. 2009 (3a edição ).

17. Speed CA. Therapeutic ultrasound in soft tissue lesions. Rheumatology (Oxford). 2001;40(12):1331-6.

18. ter Haar G. Therapeutic ultrasound. Eur J Ultrasound. 1999;9(1):3-9.

19. Clark GT, Adachi NY, Dornan MR. Physical medicine procedures affect temporomandibular disorders: a review. J Am Dent Assoc. 1990;121(1):151-62.

20. der Windt DIA v, van der Heijden GJ, van den Berg SG, ter Riet G, de Winter AF, Bouter LM. Ultrasound therapy for musculoskeletal disorders: a systematic review. Pain. 1999;81(3):257-71.

21. Seco J, Kovacs FM, Urrutia G. The efficacy, safety, effectiveness, and costeffectiveness of ultrasound and shock wave therapies for low back pain: a systematic review. Spine J. 2011;11(10):966-77.

22. Ebadi S, Henschke N, Nakhostin Ansari N, Fallah E, van Tulder MW. Therapeutic ultrasound for chronic low-back pain. Cochrane Database Syst Rev. 2014;3:CD009169.

23. Cairns BE, Gazerani P. Sex-related differences in pain. Maturitas. 2009;63(4): 292-6.
24. Craft RM, Mogil JS, Aloisi AM. Sex differences in pain and analgesia: the role of gonadal hormones. Eur J Pain. 2004;8(5):397-411.

25. Fillingim RB, King CD, Ribeiro-Dasilva MC, Rahim-Williams B, Riley JL 3rd. Sex, gender, and pain: a review of recent clinical and experimental findings. J Pain. 2009;10(5):447-85.

26. Riley JL III, Robinson ME, Wise EA, Myers CD, Fillingim RB. Sex differences in the perception of noxious experimental stimuli: a meta-analysis. Pain. 1998; 74(2):181-7.

27. Almeida ICGB. SÃ KN, Silva M, Baptista Ao, Matos MA, Lessa Ãn. Chronic low back pain prevalence in the population of the city of Salvador. Rev Bras Ortop. 2008;43(3):96-102.

28. Airaksinen O, Brox J, Co C, Hildebrandt J, Klaber-Moffett J, Kovacs F, et al. Chapter 4 European guidelines for the management of chronic nonspecific low back pain. Eur Spine J. 2006;15:\$192-300.

29. Waxman R, Tennant A, Helliwell P. A prospective follow-up study of low back pain in the community. Spine. 2000;25(16):2085-90.

30. Kopec JA, Sayre EC, Esdaile JM. Predictors of back pain in a general population cohort. Spine. 2004;29(1):70-7.

31. Low JA, Reed A. Eletroterapia Explicada: princípios e prática. Ed Manole; 2001

32. Al'Absi M, Buchanan T, Lovallo WR. Pain perception and cardiovascular responses in men with positive parental history for hypertension. Psychophysiology. 1996;33(6):655-61.

33. Deyo RA, Weinstein JN. Low Back pain. N Engl J Med. 2001;344(5):363-70.

34. Resolution WHA55.23. Diet, physical activity and health. In: Fifty-fifth World Health Assembly, Geneva, 13--18 May 2002. Volume 1. Resolutions and decisions, annexes. Geneva: World Health Organization; 2002 (document WHA55/2002/REC/1):28--30.

35. Krismer M, Van Tulder M. Low back pain (non-specific). Best Pract Res Clin Rheumatol. 2007;21(1):77-91.

36. Kovacs FM, Abraira V, Peña A, Martín-Rodríquez JG, Sánchez-Vera M, Ferrer E, et al. Effect of firmness of mattress on chronic non-specific low-back pain: randomised, double-blind, controlled, multicentre trial. Lancet. 2003; 362(9396):1599-604

37. Costa LDM, Maher CG, McAuley JH, Hancock MJ, Oliveira WD, Azevedo DC, et al. The Brazilian-Portuguese versions of the McGill pain questionnaire were reproducible, valid, and responsive in patients with musculoskeletal pain. J Clin Epidemiol. 2011;64(8):903-12.

38. Bird ML, Callisaya ML, Cannell J, Gibbons T, Smith ST, Ahuja KD. Accuracy, validity, and reliability of an electronic visual analog scale for pain on a touch screen tablet in healthy older adults: a clinical trial. Interact J Med Res. 2016;5(1):e3.

39. Dionne CE, Dunn KM, Croft PR, Nachemson AL, Buchbinder R, Walker BF, et al. A consensus approach toward the standardization of back pain definitions for use in prevalence studies. Spine. 2008;33(1):95-103.

40. Hoy D, Bain C, Williams G, March L, Brooks P, Blyth F, et al. A systematic review of the global prevalence of low back pain. Arthritis Rheumatism. 2012:64(6):2028-37.

41. Ebadi S, Ansari NN, Naghdi S, Jalaei S, Sadat M, Bagheri H, et al. The effect of continuous ultrasound on chronic non-specific low back pain: a single blind placebo-controlled randomized trial. BMC Musculoskelet Disord. 2012;13:192.

42. Melzack R. The McGill pain questionnaire: major properties and scoring methods. Pain. 1975;1(3):277-99.

43. Melzack R. The short-form McGill pain questionnaire. Pain. 1987:30(2):191-7.

44. Roland M, Morris R. A study of the natural history of back pain. Part I: development of a reliable and sensitive measure of disability in low-back pain. Spine (Phila Pa 1976). 1983;8(2):141-4.

45. Jang $H$, Lee $H$. Meta-analysis of pain relief effects by laser irradiation on joint areas. Photomed Laser Surg. 2012;30(8):405-17.

46. Kulekcioglu S, Sivrioglu K, Ozcan O, Parlak M. Effectiveness of low-level laser therapy in temporomandibular disorder. Scand J Rheumatol. 2003;32(2):114-8.

47. Campana VR, Moya M, Gavotto A, Soriano F, Juri HO, Spitable S, et al. The relative effects he-ne laser and meloxicam on experimentally induced inflammation. Laser Ther. 1999;11(1):36-48.

48. Kirschbaum C, Steyer R, Eid M, Patalla U, Schwenkmezger P, Hellhammer $\mathrm{DH}$. Cortisol and behavior: 2. Application of a latent state-trait model to salivary cortisol. Psychoneuroendocrinol. 1990;15(4):297-307.

49. Carnevalli CM, Soares CP, Zângaro RA, Pinheiro AL, Silva NS. Laser light prevents apoptosis on Cho K-1 cell line. J Clin Laser Med Surg. 2003;21(4):193-6.

50. Bortoletto R. Silva Nd, Zangaro R, Pacheco M, Da Matta R, Pacheco-Soares C. mitochondrial membrane potential after low-power laser irradiation. Lasers Med Sci. 2004;18(4):204-6. 
51. Prentice WE. Modalidades Terapêuticas para Fisioterapeutas. Artmed. 2004; 2 ed. v1. pg 472

52. Page MJ, Green S, Kramer S, Johnston RV, McBain B, Buchbinder R.

Electrotherapy modalities for adhesive capsulitis (frozen shoulder). Cochrane Database Syst Rev. 2014;10:CD011324.

53. Noori SA, Rasheed A, Aiyer R, Jung B, Bansal N, Chang KV, et al. Therapeutic ultrasound for pain Management in Chronic Low Back Pain and Chronic Neck Pain: a systematic review. Pain Med. 2019;31:155-161.

54. Dyson M. Mechanisms involved in therapeutic ultrasound. Physiotherapy. 1987;73(3):116-20

\section{Publisher's Note}

Springer Nature remains neutral with regard to jurisdictional claims in published maps and institutional affiliations.

Ready to submit your research? Choose BMC and benefit from:

- fast, convenient online submission

- thorough peer review by experienced researchers in your field

- rapid publication on acceptance

- support for research data, including large and complex data types

- gold Open Access which fosters wider collaboration and increased citations

- maximum visibility for your research: over $100 \mathrm{M}$ website views per year

At BMC, research is always in progress.

Learn more biomedcentral.com/submissions 